\title{
AN APPRAISAL OF CONTAINERIZATION IN PORTS OF WESTERN AND EASTERN NIGERIA
}

\author{
Olapoju Olabisi Michael ${ }^{1}$ \\ ${ }^{1}$ Department of Geography, Obafemi Awolowo University, Ile-Ife, Nigeria, Africa
}

Received 28 January 2019; accepted 25 March 2019

\begin{abstract}
The study appraised containerization market share among the two port divisions in Nigeria-Western and Eastern ports. Container throughput of all the ports within these divisions between 1995 and 2014 were extracted from Annual Statistical Reports of operation of the Nigerian Ports Authority in order to achieve a comparative perspective of their shares of the container trade. HHI was adopted to determine the level of concentration of container trade in any of the ports. Study revealed that Western Ports (LPC and TCIPC) have higher percentage shares of container throughout the study period, thus becoming more concentrated than the Eastern counterparts. Generally, concentration index for all the ports showed highest concentration of 0.51 both in 2005 and 2006 and the lowest index of 0.4 in 2014. Study concluded that geographical location, extensiveness of the hinterland and relative size of ports as factors responsible for the resultant index of the ports.
\end{abstract}

Keywords: containerization, Western and Eastern ports, concentration index, HHI.

\section{Introduction}

Seaport development epochs in Nigeria have been widely studied by Ogundana. Worthy of note are the location factor in changing seaport significance in Nigeria (Ogundana, 1971), Oscillating seaport location in Nigeria (Ogundana, 1972), factors influencing the fortunes of ports in the Niger Delta (Udo and Ogundana, 1966), seaport development; multinational cooperation in West Africa (Ogundana, 1974) and changing the capacity of Nigeria's seaport entrances (Ogundana, 1976). Most of these studies have similar undertone which especially pointed to changing significance in the fortunes of Nigerian seaports occasioned by port concentration which is in turn due especially to certain factors including but not limited to site characteristics, investment in port facilities, organization of port facilities, port capacity, development of economy and hinterland transport. Though not much was said about container technology in all his studies, perhaps because of the nascency of the containerization in Nigerian seaports at the period. However, the adoption of containerization in Nigerian seaports, perhaps may have provided answer to one of the worries of Ogundana-port facilities.

Nigeria's decision to adopt container technology in 1968 was a step in right direction as the adoption of containerization has already become ubiquitous maritime object across the globe (Levinson, 2006). The adoption of containerization into Nigerian seaports not only brought about

${ }^{1}$ Corresponding author: oolapoju@oauife.edu.ng 
an enhanced, specialized, mechanical and standardized method of operations (Ukpong, 1998) but also led to the construction of the first container berth in Nigeria which was commissioned in 1968 as part of the second Apapa Wharf extension. This was followed by the commissioning of the $1005 \mathrm{~m}$ berthing facility as part of the Third Apapa Wharf extension in 1979. Though there are container handling facilities in other seaports in the country, the Container Terminal Apapa is the major hub of container cargo handling and the only specialized container port in Nigeria. Container revolution also led to the development of other port facilities such as the Tin-Can Island and Roro Ports which equally have facilities for handling container trade (Odumosu, 1998; Ukpong 1998).

By 1987, the first major study on containerization was carried out by Filani and Ikporukpo (1987) especially focusing on the trends and patterns of container technology in Nigeria maritime trade between 1968 and 1987. It took another 26 years for another study on the diffusion of containerization into Nigeria transport system to be carried out by Aderamo and Adeyanju (2013). Though these two significant studies were carried out both at the two divides of port concession in Nigeria (pre and post concession), it is noteworthy to state that none of the studies emphasized the container market share and concentration level at ports in the country. The focus of this study is to assess comparative performance of container terminals and also to explain port market concentration due to introduction of containerization into Nigerian maritime trade.

The paper is structured as follows. In section 2 relevant literature on market concentration is provided plus information on Nigerian ports. Section 3 provides information on methodologies. Section 4 focuses on results, discussion and policy implication. Finally, section 5 presents the conclusion and need for future research.

\section{Literature}

Studies on container terminals, especially on performance and market concentration are replete in the literature. This is so, because of the growing significance of container terminals within the global supply chains (Hsu, 2013). Specifically, annual growth rate of the world container traffic has been above the world trade growth because of the containerization of more commodity types and the deployment of more large containerships to accommodate increasing number of containers (UNCTAD, 2014; Neylan, 2015). Again, several international container business players are expanding to achieve global visibility.

Some significant studies on port concentration include the earliest work of (Taaffe et al., 1963) on Nigerian and Ghanaian ports and Rimmer (1967) followed by that of Hayuth (1981). These studies have shown the significance of market concentration at emerging some few port locations as hub or load centres. However, based on methodologies, Marti (1988) and Hayuth (1988) have examined container traffic concentration in the North America market using Shift-Share Analysis (S-SA) and the Gini coefficient. In another study, Notteboom (1997) has investigated the concentration and deconcentration tendencies of port traffic to reveal the emergence process of load centre in European port system. In addition, Wang and Cullinane (2004) adopted Hirshman- 
Herfindahl Index (HHI), the Gini coefficient and Shift-Share Analysis to examine port traffic concentration at Hamburg, US and China ports between 1992 and 2002. Most of the studies on market concentration were carried out in ports of the developed economies and developed ports of emerging economies, in order to reveal current market status of ports in such regions. No known studies on container traffic concentration in Nigerian ports is available. This study sets out to replicate studies on container traffic concentration in heterogeneous port systems of Western and Eastern ports in Nigeria, with each having different characteristics especially in terms of site and location, cargo flow and types, port-hinterland coverage, port facilities and port management and administration systems. This is necessary because of the significance of Nigerian ports to the country's international trade as the ports account for some 99 per cent by volume and 95 per cent by value of the country's total imports and exports. This study is also significant especially in the face of the country's port challenges of inefficiency occasioned by congestion, hinterland connectivity problem, long turnaround time of ship, long cargo dwell time and infrastructure deficiency, which have reduced its significance in the West African sub region.

Nigeria has a total of six seaports and twentytwo terminals which are administratively fused into two major groups by the Nigerian Ports Authority (NPA), namely, the Western and Eastern ports (Nigerian Ports Today, 2015). The Western ports are of four types which presently have been fused into two major complexes. These are the Lagos Port Complex (LPC) (Container Terminal and Apapa Port) and Tin Can Island Port
Complex (TCIPC) (Tin-Can Island port and Ro-ro Terminal). The Eastern ports include the Delta Port Complex (Warri port), Rivers port complex (Port Harcourt and Onne ports) and Calabar port complex. The significance of these ports is in their regional spread along the coastal lines and estuaries of the most important navigable rivers as well as their capacity to accommodate relatively considerable size of container ships.

\section{Methods}

Data for this study was extracted from Annual Statistics of operations of ports and terminals submitted by all terminal operators to Nigerian Ports Authority (NPA). The data included both the inward and outward container traffic in all the ports for 20 years, between 1995 and 2014. The index considered was the number of twenty-foot equivalent units (TEUs) containers handled by the terminals within the period under consideration.

Frequency tables and charts were used to display annual container traffic in all the ports under consideration to reveal comparative records of container traffic handled by Western and Eastern ports. Herfindahl Hirschman Index (HHI) was used to measure the degree of market concentration among the ports of study. Calkins (1983) has described HHI as a responsive tool for the analysis of asymmetry market shares. According to Pan et al (2015), $\mathrm{HHI}$ is useful for indicating the degree of competition among firms based on market concentration, thus becoming an efficient screening device or indicators for regulators (Rhoades, 1995). Other much used measures of concentration include the Gini coefficient, which is the most measure of inequality 
initially deployed to measure the degree of concentration or inequality in income. There is also the Concentration ration (CR) which is used to determine the market share owned by the largest number of firms in an industry. $\mathrm{HHI}$ is given as Eq. 1:

$\mathrm{H}=\frac{\sum_{i=1}^{n} T E U i 2}{\left(\sum_{i=1}^{n} T E U \mathrm{i}\right) 2}$

Where $1 / n<\mathrm{H}<1$

$H$ - represents the concentration index for all the port system;

$n$ - represents the number of ports in the system;

$\mathrm{TEU}_{\mathrm{i}}{ }^{2}$ - represents square of total twenty foot equivalent units recorded per port;

$\left(T E U_{i}\right)^{2}$ - represents square of total twenty foot equivalent units recorded by all the ports.

HHI ranges from $1 / n$ to 1 . If the value of the $\mathrm{HHI}$ ranges to 1 , the port system attains full concentration - this implies that the market is dominated by a specific port. On the other hand, the system is perfectly competitive when the index reaches the minimum of value of $1 / n$, implying that the market share is divided equally for all the ports.

\section{Results}

\subsection{Overview of Western and Eastern Ports' Container Traffic}

Table 1 and 2 show container traffic annual percentage contribution in all the ports of Western and Eastern ports in Nigeria. For all the ports, a total of 11045766 TEUs were recorded between 1995 and 2014. Of this record, LPC has an overall traffic share of $50.7 \%$ followed by TCIPC with $38.5 \%$. Other ports traffic recorded were Onne (8.8\%), Port Harcourt (0.9\%), Warri and Calabar ports, $0.8 \%$ and $0.3 \%$ respectively. However, annual percentage records showed that LPC had dominant records of container traffic from 1995 when it recorded 58.9\% annual traffic up till 2008 with a reduced annual record of $46.4 \%$. By 2009 , TCIPC had overtaken LPC in traffic dominance by contributing an annual percentage record of $50.4 \%$. This dominance continued through to 2014 where it recorded annual percentage of $48.6 \%$ against LPC with $38.5 \%$; Warri, $0.3 \%$; Onne, $12.6 \%$; Port Harcourt, $0.0 \%$; and Calabar, $0.0 \%$, respectively. Annual record of $0.0 \%$ reported for Port Harcourt for the latter half of the period of this study did not imply absence of data but a completely insignificant number of container handled in some occasions and zero record for some other years. For instance, between 2005 and 2008, no record of any container traffic was reported. However, in 2009, out of the total annual record of 653584 TEUs, Port Harcourt port only recorded 215 TEUs. Also, in 2010, record showed an abysmally low traffic of 2 TEUs out of the total annual traffic of 685937 TEUs for all the ports. Similar records was reported for Calabar port especially in 1996 and 1997, 2001, 2012, 2013 and 2014 where container traffic was 207 TEUs, 111 TEUs, 351 TEUs, 431 TEUs, 377 TEUs and 115 TEUs respectively. 


\section{Table 1}

Nigerian Ports' Container Traffic

\begin{tabular}{|c|c|c|c|c|c|c|}
\hline Year & LPC & TCIPC & Warri & Onne & P/Harcourt & Calabar \\
\hline 1995 & 115990 & 53544 & 5808 & 10757 & 9707 & 1111 \\
\hline 1996 & 118858 & 54959 & 6374 & 9544 & 9902 & 207 \\
\hline 1997 & 153100 & 53610 & 6418 & 11248 & 12196 & 111 \\
\hline 1998 & 186767 & 69647 & 4452 & 9747 & 15155 & 889 \\
\hline 1999 & 215005 & 96522 & 4192 & 7607 & 19563 & 1465 \\
\hline 2000 & 211065 & 100326 & 4194 & 11764 & 15743 & 1137 \\
\hline 2001 & 305065 & 134723 & 6532 & 33411 & 3098 & 351 \\
\hline 2002 & 340130 & 135669 & 7765 & 58130 & 3128 & 975 \\
\hline 2003 & 336423 & 149524 & 5082 & 86291 & 7900 & 3376 \\
\hline 2004 & 325199 & 119652 & 4857 & 53922 & 4665 & 5659 \\
\hline 2005 & 382532 & 144524 & 3248 & 37402 & 0 & 7536 \\
\hline 2006 & 395147 & 166186 & 3007 & 31932 & 0 & 3085 \\
\hline 2007 & 248348 & 121851 & 1604 & 31138 & 0 & 3138 \\
\hline 2008 & 284180 & 280943 & 2512 & 42803 & 0 & 2544 \\
\hline 2009 & 266522 & 329373 & 4099 & 51831 & 215 & 1544 \\
\hline 2010 & 277288 & 344002 & 3940 & 59454 & 2 & 1251 \\
\hline 2011 & 336864 & 420869 & 1962 & 79429 & 70 & 783 \\
\hline 2012 & 327626 & 452215 & 2066 & 98144 & 115 & 431 \\
\hline 2013 & 369052 & 507348 & 2891 & 111553 & 19 & 377 \\
\hline 2014 & 408002 & 515898 & 2671 & 133863 & 11 & 115 \\
\hline TOTAL & $\mathbf{5 6 0 3 1 6 3}$ & $\mathbf{4 2 5 1 3 8 5}$ & $\mathbf{8 3 6 7 4}$ & $\mathbf{9 6 9 9 7 0}$ & $\mathbf{1 0 1 4 8 9}$ & $\mathbf{3 6 0 8 5}$ \\
\hline
\end{tabular}

Source: NPA Statistics of Operations Between 1995 and 2014

\section{Table 2}

Percentage Container Traffic of Each Port

\begin{tabular}{|c|c|c|c|c|c|c|c|}
\hline Year & Total Traffic & LPC & TCIP & Warri & Onne & P/Harcourt & Calabar \\
\hline 1995 & 196917 & $58.9 \%$ & $27.2 \%$ & $2.9 \%$ & $5.5 \%$ & $4.9 \%$ & $0.6 \%$ \\
\hline 1996 & 199844 & $59.5 \%$ & $27.5 \%$ & $3.2 \%$ & $4.8 \%$ & $5.0 \%$ & $0.1 \%$ \\
\hline 1997 & 236683 & $64.7 \%$ & $22.7 \%$ & $2.7 \%$ & $4.8 \%$ & $5.2 \%$ & $0.0 \%$ \\
\hline 1998 & 286657 & $65.2 \%$ & $24.3 \%$ & $1.6 \%$ & $3.4 \%$ & $5.3 \%$ & $0.3 \%$ \\
\hline 1999 & 344354 & $62.4 \%$ & $28.0 \%$ & $1.2 \%$ & $2.2 \%$ & $5.7 \%$ & $0.4 \%$ \\
\hline 2000 & 344229 & $61.3 \%$ & $29.1 \%$ & $1.2 \%$ & $3.4 \%$ & $4.6 \%$ & $0.3 \%$ \\
\hline 2001 & 483180 & $63.1 \%$ & $27.9 \%$ & $1.4 \%$ & $6.9 \%$ & $0.6 \%$ & $0.1 \%$ \\
\hline 2002 & 545797 & $62.3 \%$ & $24.9 \%$ & $1.4 \%$ & $10.7 \%$ & $0.6 \%$ & $0.2 \%$ \\
\hline 2003 & 588596 & $57.2 \%$ & $25.4 \%$ & $0.9 \%$ & $14.7 \%$ & $1.3 \%$ & $0.6 \%$ \\
\hline 2004 & 513954 & $63.3 \%$ & $23.3 \%$ & $0.9 \%$ & $10.5 \%$ & $0.9 \%$ & $1.1 \%$ \\
\hline 2005 & 575242 & $66.5 \%$ & $25.1 \%$ & $0.6 \%$ & $6.5 \%$ & $0.0 \%$ & $1.3 \%$ \\
\hline 2006 & 599357 & $65.9 \%$ & $27.7 \%$ & $0.5 \%$ & $5.3 \%$ & $0.0 \%$ & $0.5 \%$ \\
\hline 2007 & 406079 & $61.2 \%$ & $30.0 \%$ & $0.4 \%$ & $7.7 \%$ & $0.0 \%$ & $0.8 \%$ \\
\hline 2008 & 612982 & $46.4 \%$ & $45.8 \%$ & $0.4 \%$ & $7.0 \%$ & $0.0 \%$ & $0.4 \%$ \\
\hline 2009 & 653584 & $40.8 \%$ & $50.4 \%$ & $0.6 \%$ & $7.9 \%$ & $0.0 \%$ & $0.2 \%$ \\
\hline 2010 & 685937 & $40.4 \%$ & $50.2 \%$ & $0.6 \%$ & $8.7 \%$ & $0.0 \%$ & $0.2 \%$ \\
\hline 2011 & 839977 & $40.1 \%$ & $50.1 \%$ & $0.2 \%$ & $9.5 \%$ & $0.0 \%$ & $0.1 \%$ \\
\hline 2012 & 880597 & $37.2 \%$ & $51.4 \%$ & $0.2 \%$ & $11.1 \%$ & $0.0 \%$ & $0.0 \%$ \\
\hline 2013 & 991240 & $37.2 \%$ & $51.2 \%$ & $0.3 \%$ & $11.3 \%$ & $0.0 \%$ & $0.0 \%$ \\
\hline 2014 & 1060560 & $38.5 \%$ & $48.6 \%$ & $0.3 \%$ & $12.6 \%$ & $0.0 \%$ & $0.0 \%$ \\
\hline Total & $\mathbf{1 1 0 4 5 7 6 6}$ & $\mathbf{5 0 . 7 \%}$ & $\mathbf{3 8 . 5} \%$ & $\mathbf{0 . 8} \%$ & $\mathbf{8 . 8} \%$ & $\mathbf{0 . 9 \%}$ & $\mathbf{0 . 3 \%}$ \\
\hline
\end{tabular}

Source: Author's Analysis (2019) 


\subsection{HHI of Container Concentration in Western and Eastern Ports in Nigeria}

This section provides information on HHI of each of the Western and Eastern ports as well as the overall port system in the country. Fig 1 shows initial tendency towards concentration for LPC especially with initial rise in HHI from 0.35 in 1996 to 0.42 in 1997 . This was sustained till 1998 before the ensuing fluctuations from 1999 to 2004 before the highest index of concentration was recorded in 2005. This was later followed by unabated deconcentration as the port witnessed its lowest index of 0.14 in 2012 through
2013 before a meagre increase to 0.15 in 2014. However, its regional counterpart, TCIPC has no significant tendency towards concentration especially considering the initial HHI of 0.07 which continued through till 0.09 in 2007 where any sign of accretion was witnessed. This was later followed by 0.21 in 2008 and strove towards increase from 0.21 to 0.26 , highest so far, before a dip to 0.23 in 2014 .

Contrariwise, as shown in Figure 2, Eastern ports revealed records of deconcentration across all the ports in the region. The highest but rather negligible index recorded was 0.02 by Onne port in 2003 and 2014.

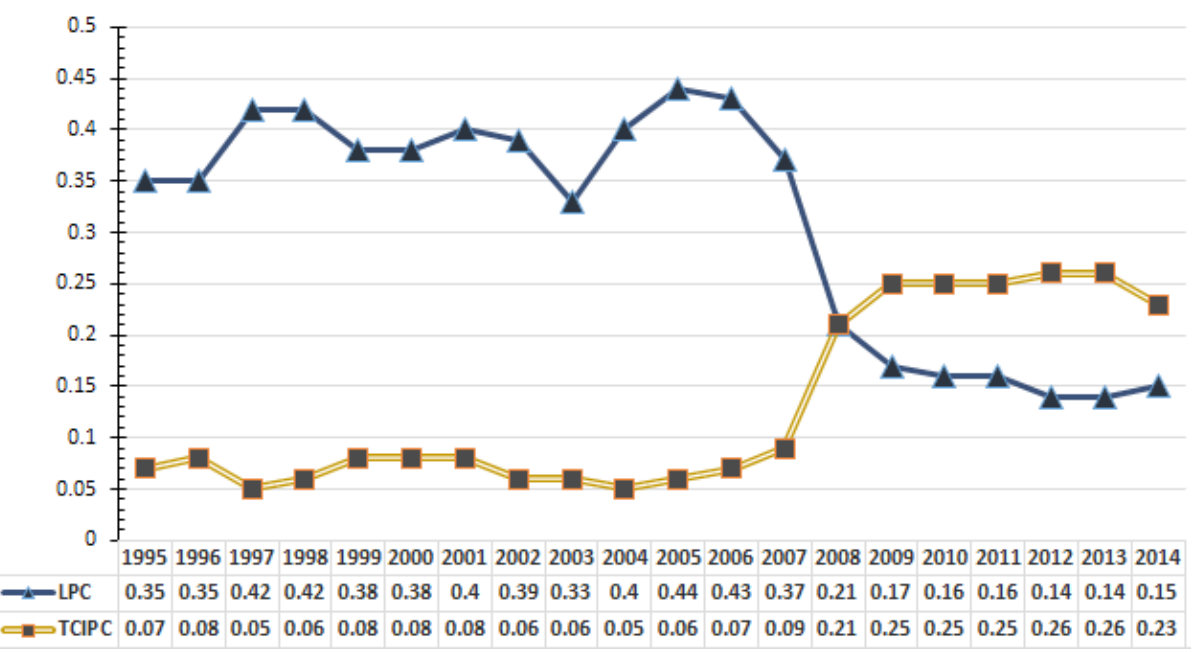

Fig. 1.

HHI of Western Ports, 1995-2014

Source: Author's Analysis 


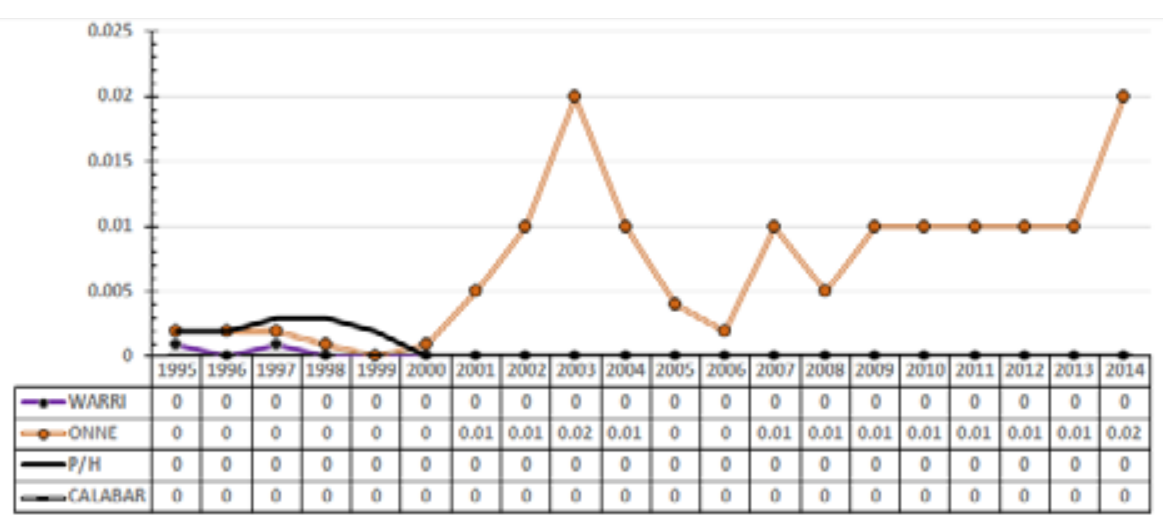

Fig. 2.

HHI of Eastern ports, 1995-2014

Source: Author's Analysis

Figure 3 illustrates a combined index for Western and Eastern ports in Nigeria. The chart indicates initial tendency towards concentration as it moves from 0.43 in 1995 to reach its first peak in 1998 before a decline in 1999 and a further decline in 2000. A rise in the index in 2001 was later followed by a decline in 2002 and a further most significant decline in concentration in 2003. However, this was followed by an increasing trend from 2004 up till 2005 where a second but higher peak of concentration was attained. This was sustained till 2006 before an unabated decline began in 2007 which would last till 2014 where an index of concentration of 0.4 was recorded.

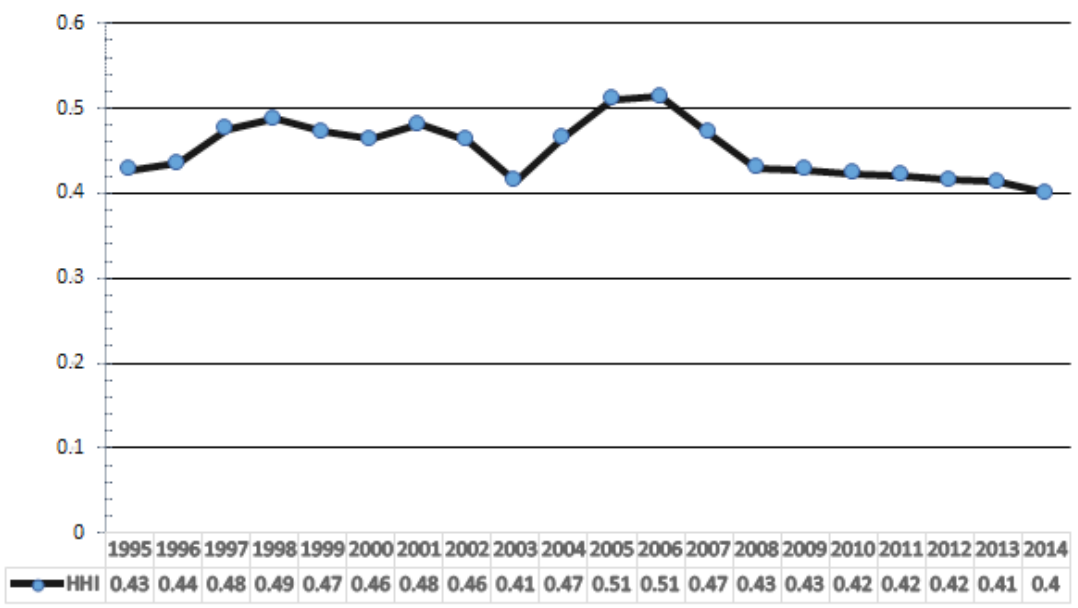

Fig. 3.

HHI of Western and Eastern port system in Nigeria, 1995-2014

Source: Author's Analysis 


\section{Discussion}

The study was carried out to appraise containerization market share among the two port divisions in Nigeria-Western and Eastern ports. Container throughput of all the ports within these divisions were considered to achieve a comparative perspective of their shares of the container trade. HHI was adopted to determine the level of concentration of container trade in any of the ports. General findings revealed that Western Ports have higher percentage share of container market throughout the study period, thus becoming more concentrated than the Eastern counterparts. The concentration level recorded by Western ports over the Eastern ports may not be unconnected with comparative advantage of geographical location of these ports. This has been initially highlighted by Udo and Ogundana (1966) and Ogundana (1970) as a key factor of port significance in Nigeria. According to Ogundana (1970), Lagos (Western Ports) conspicuous position, as the only entrance in about 130 miles of Nigerian coast, makes it the obvious outlet for a large area. This tendency has been seen as a common feature of prosperous global ports as buttressed by (Tavassey et al., 2011) who also emphasized port site characteristic as a determinant factor in choice of shipping route.

Besides, the nature of concentration recorded could also be influenced by the extensiveness of the hinterland economy which in turns determines the extent of areas of destination of goods imported through ports. The significance of hinterland has been established by Charlier (1983), Notteboom (2008) and Guerrero (2014) as the first principle upon which port development is based. Again, the impact of economically and demographically larger and richer regions which tend to be involved in more diversified transport volumes and more value-added goods has been emphasized as significant to port market concentration and other attendant increasing income (Banister, 2012; Ducruet et al., 2015; Shi and Li, 2016). The finding further alluded to Fleming and Hayuth (1994) consideration of spatiality and centrality of ports as significant to traffic concentration. Fleming and Hayuth (1994) described the influence of centrality as a definitive locational attribute that determines the strategic role of each port within a transport system. According to them, location of port in the midst of a large hinterland attracts extra traffic generation from the hinterland. The case of Western ports in Lagos, Nigeria is similar to Shangai and Xiamen ports in Eastern China and that of Antwerp and Le Havre in North-Western European market.

Another factor adduced for the recorded container market concentration of Western and Eastern ports in Nigeria may be connected with relative size of ports. This finding supports Ogundana (1970) finding that bigger ports generate increasingly greater pulls than their relatively smaller neighbours. According to Ogundana (1970), the concentration in big port towns of institutional services for foreign trade, affords such ports external economies. This case is particularly significant to higher concentration index recorded by Western ports above the Eastern ports, because of Lagos, the host city for Western ports with its unarguable leading function in the nation's economy. 


\section{Conclusion and Implications}

The adoption of containerization as veritable innovation in global maritime trade is no longer a ruse. Likewise its significance and capability to determining port's fortune or misfortune is unarguable. However, understanding the share of nation's port in global containerization helps in honing its competitive edge both at local, regional and at global scale.

Western and Eastern ports in Nigeria have contributed significantly to the country's port system and general international and local maritime trade. However, the study has shown that Western ports have more container concentration than the Eastern counterpart due in essence to factors of port site and location, spatiality and centrality of port as well as extensiveness and richness of hinterland economy.

This study offers important implications for academic and management considerations. For academic on one hand, the study has provided empirical information on Nigerian ports container concentration situation at national level, thus requiring further empirical studies showing comparative concentration studies with their global counterparts. On the other hand, management of ports require to assess the performance of their individual port terminals to understand their relative and comparative market share in order to foster their competitiveness and relative significance within their region.

\section{References}

Aderamo, A.J.; Adeyanju, J.A. 2013. Diffusion of container packaging method into the Nigerian transport system, Journal of Asian Scientific Research 3(1): 39-56.
Banister, D. 2012. Transport and economic development: reviewing the evidence, Transportation Review 32(1): 1-2.

Calkins, S. 1983. The new merger guidelines and the Herfindahl-Hirschman Index, California Law Review 71(6): 402-429.

Charlier, J.J. 1983. Ports et regions francaises: line analyse macro-geographique [In English: French ports and regions: line macro-geographical analysis], Acta Geographica Lovaniensia 24: 1-198.

Ducruet, C.; Itoh, H.; Joly, O. 2015. Ports and the local embedding of commodity flows, Papers in Regional Science 94(3): 607-627.

Filani, M.O.; Ikporukpo, C.O. 1987. Containerization in Nigeria: trends and patterns, Maritime Policy \& Management: The flagship journal of international shipping and port research 14(3): 185-195.

Fleming, D.K.; Hayuth, Y. 1994. Spatial characteristics of transportation hubs: centrality and intermediacy, Journal of Transportation Geography 2: 3-18.

Guerrero, D. 2014. Deep-sea hinterlands: Some empirical evidence of the spatial impact of containerization, Journal of Transportation Geography 35: 84-94. http://dx.doi. org/10.1016/j.jtrangeo.2014.01.010.

Hayuth, Y. 1981. Containerisation and the load centre concept, Economic Geography 57(2): 160-176.

Hayuth, Y. 1988. Rationalization and deconcentration of the U.S. container port system, Professional Geographer 40(3): 279-288.

Hsu, W.K.K. 2013. Improving the service operations of container terminals, The International Journal of Logistics Management 24(1): 101-116.

Levinson, M. 2006. The Box: How the Shipping Container Made the World Smaller and the World Economy Bigger, Princeton, Princeton University Press. 
Neylan, P. 2015. Forecast development of world container traffic, Container Forecaster 2015 (Q1) 18.

Nigerian Ports Today. 2015. Looking forward to a 'maritime-dependent' 2016. Nigerian Ports Today, A publication of Nigerian Ports Authority 5(18): 8-10.

Notteboom, T. 1997. Concentration and load centre development in the European container port systems, Journal of Transport Geography 5(2): 99-115.

Notteboom, T. 2008. The relationship between seaports and the intermodal hinterland in light of global supply chains. In: OECD-ITF Round Table on Seaport Competition and Hinterland Connections. Available from Internet: <http://dx.doi. org/10.1787/9789282102251-en>.

Odumosu, T. 1998. Urban dimension in Nigerian ports development: the city connection. In Badejo, D. (eds). Maritime Transportation in Nigeria. Rex Charles, Ogun State, Nigeria.

Ogundana, B. 1971. The Location Factor in Changing Seaport Significance in Nigeria, Nigerian Geographical Journal 14: 71-88.

Ogundana, B. 1976. Changing the Capacity of Nigeria's Seaport Entrances, ODU: Journal of West African Studies 14: 69-88.
Ogundana, B.; Udo, R.K. 1966. Factors influencing the fortunes of ports in the Niger Delta, Scottish Geographical Magazine 83(3): 169-183.

Pan, K.; Cao, Y.; Liang, S. 2014. New tendency of Chinese container port system: 1998-2010, Geo Journal 79(3): 373-384.

Rhoades, A. S. 1995. Market Share Inequality, the HHI, and Other Measures of the Firm-Composition of a Market, Review of Industrial Organization 10: 657-674.

Shi, X.; Li, H. 2016. Developing the port hinterland: different perspectives and their application to Shenzhen Port, China, Research in Transport Business. Management 19: 42-50. http://dx.doi.org/10.1016/j.rtbm.2016.05.004.

Taaffe, E.J.; Morrill, R.L.; Gould, P.R. 1963. Transport expansion in underdeveloped countries: a comparative analysis, Geographical Review 53: 503-529.

Tavasszy, L.; Minderhoud, M.; Perrin, J.F.; Notteboom, T. 2011. A strategic network choice model for global container flows: specification, estimation and application, Journal of Transportation Geography 19: 1163-1172.

Ukpong, A.M. 1998. Nigerian Seaports and the agricultural sector: Challenges from policy discontinuities. In Badejo, D.(eds) Maritime Transport in Nigeria. Rex Charles, Ogun State, Nigeria. 